Finanse, Rynki Finansowe, Ubezpieczenia nr 4/2016 (82), cz. 2

\title{
The Impact of Value and Growth Companies on IPO Underpricing on the Polish Capital Market
}

\author{
Dariusz Zarzecki, Adrian Wołoszyn*
}

\begin{abstract}
This article groups and describes different anomalies that can appear on capital markets. We present the initial return of IPO underpricing across European markets. We present the results of empirical research conducted on the Polish capital market. This article also contains a description of the value and growth companies effect measured with the $\mathrm{P} / \mathrm{BV}$ ratio in different countries of the world. In our research we combined the IPO underpricing effect with the P/BV effect. Results show that for companies with a higher $\mathrm{P} / \mathrm{BV}$ ratio we can expect a significantly higher initial return. Moreover, when we add the January effect to these two effects, the initial return increases to $36.8 \%$.
\end{abstract}

Keywords: capital market, IPOs, underpricing

\section{Capital market anomalies}

The Capital market is an organised system for trading financial instruments to raise capital and provide security trading, and along with the currency market it constitutes the financial market (Kulpaka 2007). The capital market is also a place affected by numerous anomalies. From the viewpoint of behavioural finance, anomalies are exceptions to market efficiency generated by investors (Zielińska, Ostrowska 2013, pp. 489-499). These anomalies are frequently a reason for rejecting the efficient market hypothesis. Investors use anomalies to earn above-average rates of return. Ślepczuk distinguishes between four groups of anomalies. The first group includes calendar effects such as the January effect which explains higher stock prices in January in relation to other months. The second group comprises anomalies which are related to significant correlation coefficients. In the third group there are effects related to releasing relevant information on companies such as selling or purchasing a significant block of shares by one of the investors. In the fourth group there are anomalies related to financial ratios describing the performance of companies such as the effect of value and growth companies where companies with high $\mathrm{P} / \mathrm{BV}$ ratios, known as growth stocks, yield higher returns than companies with low $\mathrm{P} / \mathrm{BV}$ ratios, known as value stocks (Ślepczuk 2006, p. 112). Szyszka, in turn, distinguishes between five groups of anomalies: calendar-related anomalies, market overreaction, momentum strategies,

\footnotetext{
* prof. dr hab. Dariusz Zarzecki, Uniwersytet Szczeciński, e-mail: d.zarzecki@uoo.univ.szczecin.pl; dr Adrian
} Wołoszyn, Uniwersytet Szczeciński, e-mail: adrian.woloszyn@gmail.com. 
anomalies related to delayed reaction to new information, and anomalies related to company characteristics (Szyszka 2009).

The majority of empirical research conducted so far has concentrated on individual anomalies only whereas some of them can be grouped and analysed together. A good example is a combined analysis of the small company effect, as small companies are more risky and offer higher returns, with the high $\mathrm{P} / \mathrm{BV}$ effect. Another example is the combination of research on the underpricing effect, which is relatively common in capital markets, and the January effect. The underpricing effect describes the situation where the first-day closing prices are higher than the offering prices. The January effect, in turn, refers to higher returns yielded in January as compared to other months. As a consequence, when the combined effect of the two individual effects is considered, companies entering the capital market in January should yield higher returns than companies entering the market in other months. Another combination of anomalies considered in this paper may be the combined effect of underpricing and the $\mathrm{P} / \mathrm{BV}$ effect. Companies with a high $\mathrm{P} / \mathrm{BV}$ ratio, known as growth companies, are considered by investors to involve more risk and as such they yield higher returns than companies with a low P/BV ratio. Following this train of thought, the more effects are combined, the higher returns may be yielded, i.e. when investment is made in small companies of a high $\mathrm{P} / \mathrm{BV}$ ratio entering the market in January. There are, however, very few such companies in the Warsaw Stock Exchange.

\section{IPO underpricing}

IPO underpricing is one the most explored anomalies in the capital market and it describes more than 66 per cent of all the IPOs. Research into this effect was carried out in 50 countries and evidence confirming this occurring was found for all of them. IPO underpricing is measured with the initial return. The average initial closing return is estimated with the following formula:

$$
R_{I}=\frac{P_{C}-P_{o}}{P_{o}},
$$

where:

$R_{I}$ - initial return,

$P_{o}$ - offering price,

$P_{c}$ - first-day closing price.

The average initial returns on the shares of companies entering the market were positive and varied with the country. The highest returns were found for companies in developing markets such as China, India or Malaysia, where first-day closing prices doubled the offering prices. In more developed countries, in turn, such as the United States or Australia, the average initial return oscillated around $20 \%$. IPO underpricing affects both emerging 
and developed markets, practically in every period. Summary data on IPO underpricing in Europe is shown in table 1.

According to the data shown in Table 1, each country witnessed IPO underpricing in the analysed periods. The highest figures in Europe were reported for Greece between 1976 and 2007. Researchers have analysed 373 companies in total, and arrived at an average IPO underpricing equal of $50.9 \%$. The lowest levels of IPO underpricing were found for Austria in the years 1971-2010 where 103 companies were analysed and the level of underpricing amounted to $6.3 \%$. In Poland, on the other hand, IPO underpricing when based on a sample of 309 companies averaged $13.3 \%$.

\section{Table 1}

Average initial returns on IPOs in selected European countries in selected periods

\begin{tabular}{|c|c|c|c|c|c|}
\hline No. & Country & Period & $\begin{array}{l}\text { Number } \\
\text { of companies }\end{array}$ & $\mathrm{R}_{\mathrm{i}}(\%)$ & Researchers \\
\hline 1. & Austria & $1971-2010$ & 102 & 6.3 & Aussenegg; Ritter \\
\hline 2. & Belgium & 1984-2006 & 114 & 13.5 & $\begin{array}{l}\text { Rogiers, Manigart \& Ooghe; Manigart } \\
\text { DuMortier; Ritter }\end{array}$ \\
\hline 3. & Bulgaria & 2004-2007 & 9 & 36.5 & Nikolov \\
\hline 4. & Denmark & 1984-2006 & 145 & 8.1 & Jakobsen \& Sorensen; Ritter \\
\hline 5. & Finland & $1971-2006$ & 162 & 17.2 & Keloharju \\
\hline 6. & France & $1983-2010$ & 697 & 10.5 & $\begin{array}{l}\text { Husson \& Jacquillat; Leleux \& Muzyka; } \\
\text { Paliard \& Belletante; Derrien \& Womack; } \\
\text { Chahine; Ritter; Vismara }\end{array}$ \\
\hline 7. & Greece & $1976-2007$ & 373 & 50.9 & $\begin{array}{l}\text { Nounis, Kazantzis \& Thomas; Thomadakis, } \\
\text { Gounopoulos \& Nounis }\end{array}$ \\
\hline 8. & Spain & 1986-2006 & 128 & 10.9 & Ansotegui \& Fabregat; Alvarez Otera \\
\hline 9. & Netherlands & $1982-2006$ & 181 & 10.2 & $\begin{array}{l}\text { Wessels; Eijgenhuijsen \& Buijs Jenkinson, } \\
\text { Ljungqvist, \& Wilhelm; Ritter }\end{array}$ \\
\hline 10. & Ireland & 1999-2006 & 31 & 23.7 & Ritter \\
\hline 11. & Germany & $1978-2010$ & 721 & 24.7 & Ljungqvist; Rocholl: Ritter; Vismara \\
\hline 12. & Norway & 1984-2006 & 153 & 9.6 & Emilsen, Pedersen \& Saettem; Liden; Ritter \\
\hline 13. & Poland & $1991-2012$ & 309 & 13.3 & Jelic \& Briston; Wołoszyn \\
\hline 14. & Portugal & 1992-2006 & 28 & 11.6 & Almeida \& Duque; Ritter \\
\hline 15. & Switzerland & 1983-2008 & 159 & 28.0 & $\begin{array}{l}\text { Kunz, Drobetz, Kammermann \& Walchli; } \\
\text { Ritter }\end{array}$ \\
\hline 16. & Sweden & 1980-2006 & 406 & 27.3 & Rydqvist; Schuster; Simonov; Ritter \\
\hline 17. & Hungary & $1991-1998$ & 33 & 15.1 & Lyn and Zychowicz (2003) \\
\hline 18. & United Kingdom & $1959-2010$ & 4,267 & 16.2 & Dimson; Levis \\
\hline 19. & Italy & 1985-2009 & 273 & 16.4 & $\begin{array}{l}\text { Arosio, Giudici \& Paleari Cassia, Paleari } \\
\text { \& Redondi; Vismara }\end{array}$ \\
\hline
\end{tabular}

Source: own study based on: Loughran, Ritter, Rydqvist (2014).

Many concepts have been developed so far to explain this effect. These concepts derive mostly from information asymmetry, institutional explanations, behavioural finance, and other explanations. The most popular hypothesis explaining IPO underpricing was 
developed by Rock and is known as the winner's curse theory. It was first published in 1982. The theory assumes that there are two groups of investors: well informed and under informed, and each group will invest in companies when their stock prices are lower than their fair value. When the stock price is higher than the company's fair value, however, only under informed investors will invest in them. And in such a case, the new issue will yield a negative initial return. Uninformed investors are aware of this and will buy the stock only if the expected return on their investment is not negative, i.e., when the issuer will underprice on average the new issue (Rock 1982).

\section{Reasons behind underpricing and empirical evidence for Poland}

Underpricing in Poland is about the average when compared to other European countries. The first studies were carried out in 1991-1998 by three separate groups of researchers, yet the results which they arrived at varied significantly owing to the different compositions of the samples. The next measurements, made after 2000, were more consistent. They showed that the average initial return in Poland after 2000 was much lower than in 1991-1998. All the studies focused on the main market of the Warsaw Stock Exchange and have been summarized in Table 2 .

\section{Table 2}

Average underpricing in Poland

\begin{tabular}{llll}
\hline Years & $\begin{array}{l}\text { Number } \\
\text { of companies }\end{array}$ & RI (\%) & Researchers \\
\hline $1991-1998$ & 140 & 27.40 & Jelic and Bristol \\
$1991-1998$ & 103 & 54.50 & Lyn and Zychowicz \\
$1991-1998$ & 149 & 35.60 & Aussenegg \\
$1991-2006$ & 224 & 22.90 & Jelic and Briston; Ritter \\
$1991-2012$ & 309 & 13.30 & Jelic and Briston; Wołoszyn \\
$2001-2010$ & 209 & 11.40 & Zaremba, Kamiński \\
$2003-2011$ & 314 & 14.20 & Sieradzki \\
$2005-2012$ & 193 & 10.50 & Wołoszyn \\
\hline
\end{tabular}

Source: own study based on: Jelic, Briston (2003), pp. 457-484; Lyn, Zychowicz (2003), pp. 181-195;

Aussenegg (2000), pp. 69-99; Sieradzki (2013); Zaremba, Kamiński (2011); Wołoszyn (2014).

In the years 1991-1998 the Warsaw Stock Exchange witnessed 202 IPOs in total' ${ }^{1}$. According to the study by Jelic and Briston, IPO underpricing in the Polish WSE averaged $27.4 \%$. The study by Lyn and Zychowicz shows that underpricing is nearly twice as high. The reason behind this huge discrepancy is the composition of the sample. Poland is a good example of the fact that the results arrived at by different research teams vary in relation to

\footnotetext{
${ }^{1}$ www.gpw.pl/analizy_i_statystyki_pelna_wersja (10.01.2014).
} 
the composition of the sample, yet all the studies reveal unanimously that IPOs are underpriced.

The reasons behind underpricing in Poland may be derived mainly from behavioural finance theories. In a study of 193 IPOs between 2005 and 2012, certain relationships were observed, which proved to be statistically significant (at 5\%) (Wołoszyn 2014).

Investors' interest in a company is measured with the share turnover value on the first day to the offering value had a positive impact on the level of underpricing. The initial return was lower (and statistically significant) in the group of 95 companies whose share turnover value on the first day did not exceed $20 \%$ of the offering value. Only one out of two companies was underpriced, and the initial return averaged 3.5\% (median: $0.4 \%$ ). In the group of 98 companies, in turn, where the share turnover value on the first day exceeded $20 \%$, underpricing averaged $13.7 \%$ (median: $13.2 \%$ ), and nearly $90 \%$ of companies were underpriced. Such a behaviour of stock prices provides evidence which points to the occurrence of Welch's information cascade effect (Welch 1992, pp. 695-732), i.e. a situation when investors observing other investors' interest in IPO shares, tend to copy their behaviour and are more interested in the IPO themselves.

Underpricing in Poland was also affected by the January effect (which was found to be statistically significant). In the group of 9 companies entering the market in January, the initial return averaged $26.8 \%$ (median: $28.5 \%$ ), and nearly $90 \%$ of companies were underpriced. In the group of 184 companies entering the market in other months, on the other hand, the underpricing averaged $9.7 \%$ (median: $5.2 \%$ ) and concerned nearly $70 \%$ of companies. The January effect was also observed among IPOs in the NewConnect market and was found statistically significant at $10 \%$.

IPO underpricing in the main market of the Warsaw Stock Exchange was also affected by the speculation bubble in the real estate market which had been reported between May 2005 and June 2007. Four companies entering the market in that period which operated in the construction industry reported average underpricing at 70\% (median: $76.2 \%$ ) as compared to an average underpricing of 15\% (median: 10.0\%) among the other 58 companies entering the market in that period.

The moment of entry also influenced the initial return, for 93 IPOs during the bull market the underpricing averaged $15.6 \%$ (median: $10.5 \%$ ) and referred to $81 \%$ of companies, whereas for 100 companies entering the market in other periods average underpricing was estimated at $5.7 \%$ (median: $2.1 \%$ ) and referred to $60 \%$. Such behaviour of stock prices is in line with Ritter's "Hot Issue" Market theory (Ritter 1984, pp. 215-240).

Apart from the explanations behind underpricing derived from behavioural finance, the behaviour of IPO stock prices is also explained with Rock's winner's curse theory (Rock 1986, pp. 187-212). Among 136 underpriced companies the average reduction rate to subscribers amounted to $67.1 \%$ (median: $84.1 \%$ ) and was higher than among 51 overpriced companies where the reduction rate to subscribers averaged 39.4\% (median: $34 \%$ ). 
Underpricing in Poland is also related to the market of entry, and hence the market efficiency. IPO underpricing in the WSE, which is a more efficient market, averaged $10.5 \%$ (median: 5.6\%) for 193 companies as compared to the less efficient market, NewConnect, with the average underpricing at $23.9 \%$ (median: $13.3 \%$ ). Such behaviour of stock prices is in line with the theory developed by Mauer and Senbet who argue that initial returns on IPOs on more efficient markets should be lower (Mauer, Senbet 1992, pp. 55-79).

The majority of the hypotheses based on explanations derived from the information asymmetry theory do not apply to the Polish market. Baron's hypothesis, for instance, which assumes that underwriters underprice the offerings so as to reduce the marketing costs (Baron 1982, pp. 955-976), does not apply to the Polish market. The initial return among companies which introduced their own shares to the market (mostly companies operating in the financial sector or groups of companies) did not deviate significantly from those companies which employed underwriters.

IPO underpricing in the Polish capital market cannot be explained with the underwriter or auditor goodwill effect (Grinblatt, Hwang 1989, pp. 393-420). For 44 companies whose books were verified by one of the "big four" auditors (KPMG, PwC, Deloitte, and Ernst and Young), the initial return was similar to that yielded by the other 149 companies which employed less recognised underwriters. Also for the 92 companies introduced to the market by top underwriters the initial return was similar to that reported for other companies.

The overallotment option is yet another factor which does not affect the initial return in the stock market in Poland. For nine companies which offered the overallotment option initial returns were similar to those arrived at for all the other companies, which is not in line with the assumptions of the Rudd hypothesis (Rudd 1993, pp. 135-151). Nor did the lock-up agreements made in 135 offers affect the initial return on IPO shares on the Warsaw Stock Exchange in the years 2005-2012.

The hypothesis on wealth redistribution which was observed in the UK, Japan (Ibbotson, Ritter 1995, pp. 993-1016) or Malaysia (Zaremba, Kamiński 2011, p. 153), does not prove to be true for the Polish market, either. The companies owned by the State Treasury yielded slightly less initial returns than other companies.

\section{Value companies and growth companies}

The anomalies observed in the stock market are also related to financial performance. The literature of the subject distinguishes between growth stocks and value stocks, assuming that the market values companies with a positive outlook and reduces the values of companies with a gloomy outlook for the future, given their book values. As a result, growth companies reported high $\mathrm{P} / \mathrm{BV}$ ratios while value companies - a low one. The research carried out based on this distinction will show that investments in value companies yielded above-average returns, even if risk-adjusted values are considered (Ślepczuk 2006, p. 113). 
The concept of value stocks and growth stocks was first introduced to the literature by Fama and French in 1998. Initially, the classification of securities as value stocks was based not only on the price to book value ratio, but also on the price to earnings, price to cash flow, and price to dividend ratios (Fama, French 1998, pp. 1975-1999). Their results for the price to book value ratio have been summarised in Table 3. The group of high P/BV ratio comprises $30 \%$ of companies with the highest ratios in the sample, and the group of low $\mathrm{P} / \mathrm{BV}$ companies comprises $30 \%$ of stocks with the lowest ratios. Every year the ratios were recalculated and shifts among the groups were made if necessary.

\section{Table 3}

Annual rates of return related to the $\mathrm{P} / \mathrm{BV}$ ratio

\begin{tabular}{|c|c|c|c|c|c|}
\hline \multirow{3}{*}{ Country } & \multicolumn{5}{|c|}{ Average annual rate of return } \\
\hline & $\begin{array}{l}\text { total } \\
\text { market }\end{array}$ & low $\mathrm{P} / \mathrm{BV}$ & high $\mathrm{P} / \mathrm{BV}$ & difference & \multirow[t]{2}{*}{ t-statistic } \\
\hline & \multicolumn{4}{|l|}{$\%$} & \\
\hline The United States & 9.57 & 14.55 & 7.75 & 6.80 & 2.17 \\
\hline Japan & 11.88 & 16.91 & 7.06 & 9.85 & 3.49 \\
\hline The United Kingdom & 15.33 & 17.87 & 13.25 & 4.62 & 1.08 \\
\hline France & 11.26 & 17.10 & 9.46 & 7.64 & 2.08 \\
\hline Germany & 9.88 & 12.77 & 10.01 & 2.76 & 0.92 \\
\hline Italy & 8.11 & 5.45 & 11.44 & -5.99 & -0.91 \\
\hline The Netherlands & 13.30 & 15.77 & 13.47 & 2.30 & 0.44 \\
\hline Belgium & 12.62 & 14.90 & 10.51 & 4.39 & 1.99 \\
\hline Switzerland & 11.07 & 13.84 & 10.34 & 3.50 & 0.9 \\
\hline Sweden & 12.44 & 20.61 & 12.59 & 8.02 & 1.16 \\
\hline Australia & 8.92 & 17.62 & 5.30 & 12.32 & 2.41 \\
\hline Hong Kong & 22.52 & 26.51 & 19.35 & 7.16 & 1.35 \\
\hline Singapore & 13.31 & 21.63 & 11.96 & 9.67 & 2.36 \\
\hline
\end{tabular}

Source: own study based on: Fama, French (1998), pp. 1975-1999.

This effect was observed for all the markets except Italy. Moreover, the t-statistic for many countries was above 2 which indicates the significance of this effect. In 2005 Fama and French showed that the P/BV effect refers to small companies with low market capitalisation rather than big ones (Fama, French 2006, pp. 2163-2185).

\section{Data, methodology and research}

The research focused on companies which entered the Warsaw Stock Exchange between 2005 and 2012. The following companies were excluded from the sample:

- foreign-owned,

- going public without offering new shares, 
- entering the main market yet which have previously been listed in secondary markets: NewConnect or CeTO,

- listed simultaneously on other stock exchanges (dual listing),

- renewing listing in the WSE following a break,

- with different offering prices for individual and institutional investors,

- with different offering prices for different tranches,

- entering the NewConnect market, whose stocks were not traded on the first day,

- entering the main WSE market in a private offer or an offer addressed to selected shareholders,

- whose underpricing is more than twice as high as the typical variation area.

The final sample included 193 companies. They were classified into three groups according to their $\mathrm{P} / \mathrm{BV}$ ratios, i.e., ratio of the offering price multiplied by the number of shares to the book value. The latter is calculated as total assets with less debt for the year preceding IPO. The first group comprises $30 \%$ of companies with the highest $\mathrm{P} / \mathrm{BV}$ ratios, i.e. growth stocks. The second group is comprised of $40 \%$ companies with average $\mathrm{P} / \mathrm{BV}$ ratios, and the third one $-30 \%$ of companies with the lowest $\mathrm{P} / \mathrm{BV}$ ratios, the so-called value stocks. Next, initial returns were calculated for each of the groups separately. The results are shown below in Table 4.

\section{Table 4}

Initial returns on IPO in relation to $\mathrm{P} / \mathrm{BV}$ ratios

\begin{tabular}{lllll}
\hline Initial rate of return & $\begin{array}{l}\text { P/BV } \\
\text { high }\end{array}$ & medium & low & Total sample \\
\hline Number of companies & 58 & 77 & 58 & 193 \\
Arithmetic mean (\%) & 19.0 & 7.4 & 6.1 & 10.5 \\
Median (\%) & 11.3 & 5.1 & 2.4 & 5.6 \\
Standard deviation & 0.250 & 0.138 & 0.127 & 0.185 \\
Underpriced companies (\%) & 79.3 & 70.1 & 62.1 & 70.5 \\
\hline
\end{tabular}

Source: own study based on financial statements.

In line with the expectations, the results indicate that high $\mathrm{P} / \mathrm{BV}$ companies yield the highest initial returns. They also report high returns on the very day of the first listing and not only throughout the first year of listing. Nevertheless, in order to verify whether the difference is statistically significant, a t-statistic has been calculated for the difference between the average underpricing of stocks in the first and third group. The t-statistic amounted to 3.57 which informs that the research results are statistically significant at the 5\% significance level.

Moreover, the anomalies related to underpricing and high $\mathrm{P} / \mathrm{BV}$ ratio incorporated the January effect. The results accounting for this effect are shown below in Table 5 . 


\section{Table 5}

Initial rate of return on January IPOs according to $\mathrm{P} / \mathrm{BV}$ ratios

\begin{tabular}{lllll}
\hline \multirow{2}{*}{ Initial rate of return } & \multicolumn{2}{l}{$\mathrm{P} / \mathrm{BV}$} & \\
\cline { 2 - 5 } & high & medium & low & \\
\hline Number of companies & 3 & 3 & 3 & 9 \\
Arithmetic mean (\%) & 36.8 & 23.3 & 20.2 & 26.8 \\
Median (\%) & 33.2 & 16.2 & 28.5 & 28.5 \\
Standard deviation & 0.2124 & 0.1108 & 0.1479 & 0.1780 \\
Underpriced companies (\%) & 100.0 & 100.0 & 67.0 & 89.0 \\
\hline
\end{tabular}

Source: own study based on financial statements.

The combination of three anomalies significantly reduces the number of companies subject to analysis as only 9 companies went public in January. Despite this fact, and in line with the assumption, it may be observed that the highest average initial returns may be obtained when investing in high P/BV January IPOs.

\section{Conclusions}

Anomalies in the capital market are frequently discussed and analysed by researchers and investors willing to achieve the highest returns possible. The identification of certain anomalies in stock markets, such as the January effect, underpricing or the P/BV effect, offers opportunities to analyse them either separately and in combination to investigate their total effect.

This study, analysing 193 companies which went public between 2005 and 2012 reveals a significant difference between initial returns achieved by low P/BV stocks and those yielded by high P/BV stocks. When the January effect is additionally incorporated in the analysis, the returns become even higher, yet due to a small number of companies which decide to go public in January the results can not be considered statistically significant.

In Poland the main reasons explaining IPO underpricing can be traced to behavioural finance. This effect is influenced, apart from the "winner's curse", also by the cascade hypothesis, speculation bubble, the month and period of IPO, as well as the market which the company chooses to enter. Based on the study, it may be also stated that the P/BV ratio contributes to the scale of underpricing.

\section{References}

Aussenegg W. (2000). Privatization Versus Private Sector Initial Public Offerings in Poland. Multinational Finance Journal, 4, 69-99.

Baron D. 1982. A Model of the Demand for Investment Banking Advising and Distribution Services for New Issues. The Journal of Finance, 37 (4), 955-976. 
Briston R., Jelic R. (2003). Privatisation Initial Public Offerings: The Polish Experience. European Financial Management, 9 (4), 457-484.

Fama E., French K. (2006). The Value Premium and the CAPM. The Journal of Finance, 61 (5), 2163-2185.

Fama E., French K. (1998). Value versus Growth: The International Evidence. The Journal of Finance, 53 (6), 1975-1999.

Grinblatt M., Hwang C. (1989). Signalling and the Pricing of New Issues. The Journal of Finance, 44 (2), $393-420$.

Ibbotson R., Ritter J. (1995). Initial Public Offerings. In: Handbooks in OR \& MS, 9, R. Jarrow et al., Elsevier B.V. (pp. 993-1016).

Kamiński K., Zaremba A. (2011). IPOS- not so much money on the table, the cost compensation hypothesis. Argumenta Oeconomica, 26.

Kulpaka P. (2007). Giełdy w gospodarce. Warszawa: PWE.

Loughran T., Ritter J., Rydqvist K. (2014). Initial Public Offerings: International Insights, website: bear.warrington. ufl.edu/ritter/Int2014.pdf.

Lyn E., Zychowicz E. (2003). The Performance of New Equity Offerings in Hungary and Poland. Global Finance Journal, 14, 181-195.

Mauer D., Senbet L. (1992) The Effect of the Secondary Market on the Pricing of Initial Public Offerings: Theory and Evidence. Journal of Financial and Quantitative Analysis, 27 (1), 55-79.

Ostrowska E., Zielińska E. (2013). Uwarunkowania behawioralne decyzji inwestycyjnych, Prace $i$ materiały Wydziatu Zarządzania Uniwersytetu Gdańskiego, 2 (4), 489-499.

Ritter J. (1984). The 'Hot Issue' Market of 1980. The Journal of Business, 57 (2), 215-240.

Rock K. (1982). Why are New Issues Underpriced? Ph.D. Dissertation, University of Chicago, Chicago.

Rock K. (1986). Why new issues are underpriced. Journal of Financial Economics, 15, 187-212.

Rudd J. (1993). Underwriter price support and the IPO underpricing puzzle. Journal of Financial Economics, 34, $135-151$.

Sieradzki R. (2013). Does it pay to invest in IPO, Evidence from the Warsaw Stock Exchange, „NBP Working Paper” No. 139, Warsaw.

Ślepczuk R. (2006). Anomalie rynku kapitałowego w świetle hipotezy efektywności rynku. e-Finanse, 1.

Szyszka A. (2009). Finanse behawioralne nowe podejście do inwestowania na rynku kapitałowym. Poznań:Wydawnictwo Uniwersytetu Ekonomicznego w Poznaniu.

Welch I. (1992). Sequential sales, learning and cascades. The Journal of Finance, 47 (2), 695-732.

Wołoszyn A. (2014). Efekt niedowartościowania akcji na rynku kapitałowym w Polsce. Ph.D. Dissertation, unpublished, Uniwersytet Szczeciński.

www.gpw.pl/analizy_i_statystyki_pelna_wersja.

\section{WPLYW PRZEDSIĘBIORSTW ZORIENTOWANYCH NA WARTOŚĆ I PRZEDSIĘBIORSTW ZORIENTOWANYCH NA WZROST NA EFEKT NIEDOWARTOŚCIOWANIA IPO NA POLSKIM RYNKU KAPITALOWYM}

Streszczenie: W artykule zaprezentowano podział anomalii występujących na rynku giełdowym. Scharakteryzowano poszczególne anomalie. Opisano zjawisko efektu niedowartościowania oraz efektu wskaźnika P/BV. Zaprezentowano przyczyny efektu niedowartościowania na rynku w Polsce oraz średnie natychmiastowe stopy zwrotu z akcji spółek debiutujących na różnych rynkach Europy. Zaprezentowano również wyniki badań nad wskaźnikiem P/BV w wybranych krajach. Nałożono efekt niedowartościowania na efekt $\mathrm{P} / \mathrm{BV}$, co spowodowało wzrost natychmiastowych stóp zwrotu dla spółek o wysokim wskaźniku P/BV. Dodatkowo nałożono efekt stycznia na pozostałe dwa efekty, co spowodowało kolejny wzrost natychmiastowych stóp zwrotu średnio do $36,8 \%$.

Słowa kluczowe: rynek kapitałowy, pierwsze emisje (IPOs), niedowartościowanie

\section{Citation}

Zarzecki D., Wołoszyn A. (2016). The Impact of Value and Growth Companies on IPO Underpricing on the Polish Capital Market. Finanse, Rynki Finansowe, Ubezpieczenia, 4 (82/2), 325-334. DOI: 10.18276/frfu.2016.4. $82 / 2-28$. 